\title{
Focus on Osteosclerotic Progression in Primary Myelofibrosis
}

\author{
Mariarita Spampinato ${ }^{1,+} \mathbb{D}$, Cesarina Giallongo ${ }^{2,+}$, Alessandra Romano ${ }^{3,+} \mathbb{D}$, Lucia Longhitano ${ }^{1}$, \\ Enrico La Spina ${ }^{3}$, Roberto Avola ${ }^{1}$, Grazia Scandura ${ }^{3}$, Ilaria Dulcamare ${ }^{3}$, Vincenzo Bramanti ${ }^{4}$ (D),

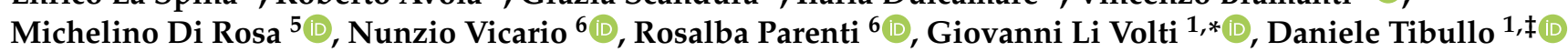 \\ and Giuseppe A. Palumbo $2, *, \ddagger$ (D)
}

check for

updates

Citation: Spampinato, M.; Giallongo,

C.; Romano, A.; Longhitano, L.; La

Spina, E.; Avola, R.; Scandura, G.; Dulcamare, I.; Bramanti, V.; Di Rosa,

M.; et al. Focus on Osteosclerotic

Progression in Primary Myelofibrosis. Biomolecules 2021, 11, 122. https:// doi.org/10.3390/biom11010122

Received: 29 November 2020

Accepted: 16 January 2021

Published: 19 January 2021

Publisher's Note: MDPI stays neutral with regard to jurisdictional claims in published maps and institutional affiliations.

Copyright: (c) 2021 by the authors. Licensee MDPI, Basel, Switzerland. This article is an open access article distributed under the terms and conditions of the Creative Commons Attribution (CC BY) license (https:/ / creativecommons.org/licenses/by/ $4.0 /)$.
1 Section of Biochemistry, Department of Biomedical and Biotechnological Sciences, University of Catania, 95123 Catania, Italy; mariaritaspampinato93@gmail.com (M.S.); lucialonghitano@icloud.com (L.L.); ravola@unict.it (R.A.); d.tibullo@unict.it (D.T.)

2 Department of Medical and Surgical Sciences and Advanced Technologies "G.F. Ingrassia", University of Catania, 95123 Catania, Italy; cesarina.giallongo@unict.it

3 Department of General Surgery and Medical-Surgical Specialties, Division of Hematology, A.O.U. "Policlinico-Vittorio Emanuele", University of Catania, 95123 Catania, Italy; sandrina.romano@gmail.com (A.R.); enricolaspina@outlook.it (E.L.S.); gra.scandura@gmail.com (G.S.); dulcamareilaria@gmail.com (I.D.)

4 Division of Clinical Pathology, “Giovanni Paolo II” Hospital-A.S.P. Ragusa, 97100 Ragusa, Italy; vincenzo.bramanti@asp.rg.it

5 Section of Human Anatomy and Histology, Department of Biomedical and Biotechnological Sciences, University of Catania, 95123 Catania, Italy; chitotriosidase@gmail.com

6 Section of Physiology, Department of Biomedical and Biotechnological Sciences, University of Catania, 95123 Catania, Italy; nunzio.vicario@unict.it (N.V.); parenti@unict.it (R.P.)

* Correspondence: livolti@unict.it (G.L.V.); palumbo.giuseppealberto@gmail.com (G.A.P.)

+ These authors equally contributed to this work as co-first.

$\ddagger$ These authors equally contributed to this work as co-last.

Abstract: Primary myelofibrosis (PMF) is a myeloproliferative neoplasm characterized by hematopoietic stem-cell-derived clonal proliferation, leading to bone marrow (BM) fibrosis. Hematopoiesis alterations are closely associated with modifications of the BM microenvironment, characterized by defective interactions between vascular and endosteal niches. As such, neoangiogenesis, megakaryocytes hyperplasia and extensive bone marrow fibrosis, followed by osteosclerosis and bone damage, are the most relevant consequences of PMF. Moreover, bone tissue deposition, together with progressive fibrosis, represents crucial mechanisms of disabilities in patients. Although the underlying mechanisms of bone damage observed in PMF are still unclear, the involvement of cytokines, growth factors and bone marrow microenvironment resident cells have been linked to disease progression. Herein, we focused on the role of megakaryocytes and their alterations, associated with cytokines and chemokines release, in modulating functions of most of the bone marrow cell populations and in creating a complex network where impaired signaling strongly contributes to progression and disabilities.

Keywords: primary myelofibrosis; bone; myeloproliferative neoplasm; bone marrow; fibrosis

\section{Introduction}

Primary myelofibrosis (PMF), known as a clonal stem cell disorder, is a chronic myeloproliferative syndrome representing the rarest and most complex of all BCR-ABL-negative myeloproliferative neoplasms (MPNs), a group of neoplastic hematological diseases comprising essential thrombocythemia (ET) and polycythemia vera (PV). From a genetic point of view, the vast majority of patients show the JAK2V617F driver mutation; the remaining population of patients usually shows either calreticulin (CALR) mutations or thrombopoietin receptor mutations (i.e., myeloproliferative leukemia, MPL) [1-4]. These mutations could also be associated with concomitant mutations to other genes such as ASXL1, IDH1/2, 
EZH2, DNMT3A and SRSF2 [4-6] and with microRNA expression level alterations [7]. The main mutations show similarity in the constitutive activation of JAK/STAT signaling. This overactivation represents a critical feature of clonal myelopoiesis in MPNs and the main biochemical pathway involved in the pathogenetic progression of myelofibrosis [8,9], playing a role in malignant expansion and compromising nonclonal hematopoietic bone marrow cell populations $[10,11]$. In addition to JAK/STAT, the involvement and hyperactivation of PI3K/AKT and NF-kB pathways in MPN disorders have been reported [12,13]. Pathological onset is due to the neoplastic transformation of a multipotent hematopoietic stem cell in the bone marrow niche and the subsequent proliferation of newly formed clones with a cancer outbreak. Therefore, as a consequence of the pathological upsurge, the bone marrow environment undergoes morphological and functional changes, inducing abnormalities in granulocytes, megakaryocytes and stromal cells, such as fibroblasts. Indeed, megakaryocytes show reduced GATA-1 protein expression coupled with increased levels of many inflammatory cytokines and growth factors (b-FGF, VEGF, PDGF) in addition to extracellular matrix constituents including fibronectin, reticulin and collagens. Disrupted cell interactions and functional variations of stroma, BM-MSC, megakaryocytes, osteoblasts, endothelium and myofibroblasts culminate in the development of bone marrow damage with an inflammatory and profibrotic environment [7].

\section{Clinical Features}

Overt PMF is the least common [14] of MPN disorders, associated with dismal prognosis with an estimated survival of $2-5$ years postdisease onset, slightly improved with current therapeutic approaches and cured with allogeneic stem cell transplantation [15-17]. The most common clinical hallmarks of PMF range from constitutional symptoms (fatigue, cachexia) to symptomatic anemia, thrombohemorrhagic events, hepatosplenomegaly with extramedullary hematopoiesis and increased susceptibility to infections and secondary cancers [18-21]. PMF is also considered a model where the neoplastic condition is present together with an elevated inflammatory status, and new therapies seem to target both aspects [22]. Bone marrow fibrosis is a key characteristic of the disease and is outlined by abnormal trafficking patterns between stem cells, hematopoietic progenitors and cell lineages in the cancer microenvironment. As a consequence, hematopoietic cells migrate from the bone marrow and give rise to extramedullary hematopoiesis, with erythroid and myeloid progenitors outside the primary niche. Hence, cancer cells migrate to external sites, such as the liver or spleen, and the expansion of the malignant clones leads to progressive hepatosplenomegaly [23]. Splenomegaly represents an unavoidable outcome and may lead to clinical complications such as splenic infarction, hemorrhages or thrombosis $[14,24-27]$, with a severe impact on prognosis.

\section{Bone Marrow Niche and Microenvironment Disruptions in PMF}

Bone marrow represents a complex and heterogenous microenvironment in which physiological homeostasis and cellular activities are based on continuous crosstalk between hematopoietic and stromal niches, in close communication throughout environmental signals, growth factors, adhesion molecules and the vascular network. The stem area is composed of stem precursors and endosteal bone surface, in which resident hematopoietic stem cells (HSCs) proliferate and differentiate [28]. Osteoblastic and vascular compartments are characterized by a heterogenous group of cells such as hematopoietic cells, fibroblasts, osteoblasts and osteoclasts, adipocytes, stromal cells (vascular endothelialcadherin-positive sinusoidal endothelial cells (SECs)), perivascular cells and mesenchymal stem cells (MSCs) [29]. In such a complex microenvironment, extracellular matrix (ECM) elements provide both mechanical and functional support [30]. The physiological mechanisms of proliferation and differentiation of HSCs are strictly dependent on homeostatic communication between bone marrow compartments. A functional imbalance of the stromal niche is considered the major factor in inducing the clinical consequences in PMF. In synthesis, it is believed that bone marrow impairment is due to multifactorial damage 
involving several cell types and the dysregulations and/or dysfunctions of biochemical elements (Figure 1).

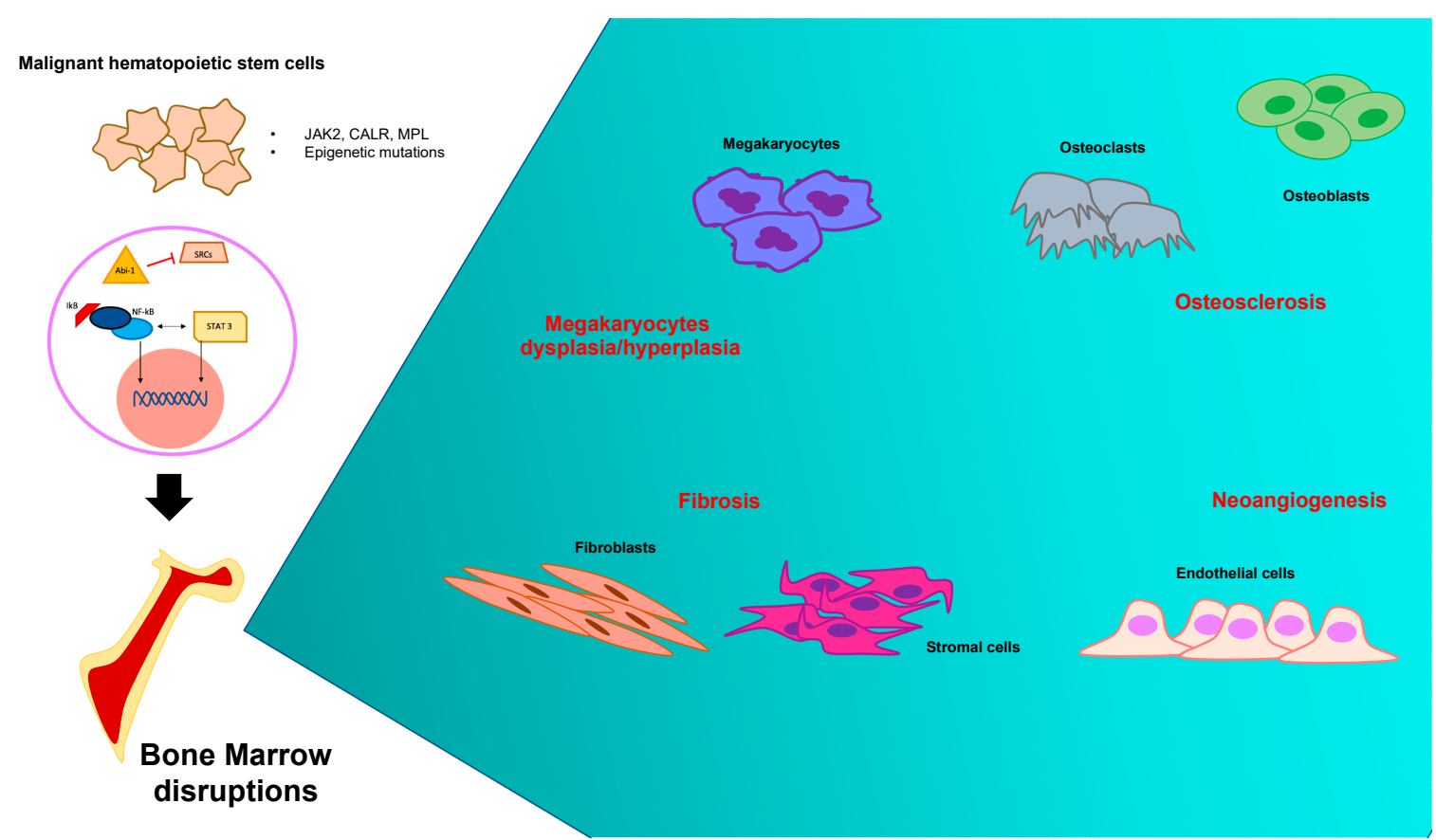

Figure 1. Pathogenetic mechanisms of primary myelofibrosis and cell lines involved: summary panel. Bone marrow dysregulations due to the neoplastic expansion of one hematopoietic stem cell produce a number of events that took place within the pathological microenvironment. The most relevant clinical consequences are neoangiogenesis, megakaryocytes hyperplasia and extensive bone marrow fibrosis, followed by osteosclerosis and bone damage.

\section{Fibrosis as PMF Banner}

PMF complexity is mainly due to the onset of bone marrow fibrosis, followed by a long sequence of cascade events. This results in hematopoiesis impairment and organ failure, culminating in osteosclerotic deposition during the late stage of the disease, which seriously impairs the health of affected patients [31]. Thus, fibrosis represents one of the cardinal hallmarks of pathological progression in PMF [32]. It seems to be mainly promoted by transforming growth factor $\beta$ (TGF- $\beta$ ), matrix metalloproteinase-9 (MMP-9) and tissue inhibitor of metalloproteinases (TIMPs) [33,34], but increased expression of growth factors such as osteocalcin, b-fibroblast growth factor (b-FGF), platelet-derived growth factor (PDGF) and vascular endothelial growth factor (VEGF) has been reported [35]. This heterogenous group of biomarkers has detrimental impacts on vascularization, the MSC niche and ECM components' stability [36]. Bone marrow fibrosis occurs as a cytokine-mediated secondary reaction toward the starting clonal malignant expansion $[37,38]$ and is characterized by disproportionate deposits of ECM proteins [39]. In vivo and in vitro studies have clarified the role of several cytokines in the aberrant stromal reaction, with a strong emphasis on the pleiotropic cytokine TGF- $\beta$ [40-42]. Analysis of biochemical markers in PMF patients showed that procollagen type $1 \mathrm{~N}$-terminal propeptide (P1NP) was significantly increased, most likely reflecting the relevant collagen deposition in bone marrow due to disease progression [43]. Fibroblast stimulation, as well as megakaryocytes activation, elicits TGF$\beta$ release, which induces large amounts of ECM proteins and cell adhesion molecules while enhancing the expression of inhibitory proteases involved in the degradation of the ECM [44]. At this point, it is easy to hypothesize a backdrop in which the microenvironment itself induces severe inflammation with consequent acidification of the medullary site [45]. This pathological picture influences HSCs and MSCs, which are subjected to clonal 
neoplastic expansion and subsequent differentiation into monocytes and megakaryocytes. The latter population releases a large number of inflammatory cytokines giving rise to a robust inflammatory cascade, responsible for the permanent alteration of the hematopoietic niche, altered crosstalk between cells and severe hematopoietic deficit [46].

\section{Megakaryocytes Role in Bone Marrow Imbalance}

Altered megakaryocytes produce a plethora of growth factors, interleukins and cytokines involved in the onset of a dysfunctional microenvironment, contributing to the neoangiogenesis and hyperactivation of both fibroblasts and osteoblasts [47]. The functional role of abnormal megakaryocytes in PMF has been investigated through different approaches, using both in vitro and in vivo models coupled with evidence from pathological assessments of clinical samples [33,34,48,49]. Histological analysis of bone marrow biopsies from PMF patients revealed megakaryocytic clusters and hyperplasia [50]. In particular, evidence from knockout mice models showed that GATA1 or the thrombopoietin (TPO) receptor, which are physiologically involved in megakaryocyte maturation, are involved in altered megakaryocytes development as well as reduced platelet counts $[34,48]$. In addition, TPO receptor overexpression gives rise to megakaryocytic and granulocytic hyperplasia with erythroblasts hypoplasia resulting in a fatal myeloproliferative condition $[33,49]$. In this regard, megakaryocyte hyperplasia has been investigated in in vitro models of CD34-positive cells isolated from PMF patients cocultured with TPO and stemcell-derived factors. This evidence shows that CD34-positive progenitor cells give rise to megakaryocytes with impaired apoptosis due to the overexpression of the antiapoptotic protein Bcl-xL, which promotes cellular hyperplasia [7]. Accumulating evidence particularly supports a potential role of IL-8 and its CXCR1 and CXCR2 receptors, both belonging to the $G$ protein-coupled receptor superfamily, on the dysfunctional phenotype of megakaryocytes. IL-8 acts as a chemoattractive and proinflammatory agent as well as a neutrophil activator, interacting with the abovementioned receptors [51]. Many different cell types are involved in IL-8 secretion, such as macrophages, fibroblasts, monocytes and megakaryocytes, at least in in vitro settings [52-54]. Hence, this cytokine and CXCRs in megakaryocytes dysfunction play a key role in this setting. In particular, IL-8 levels have been found to be significantly increased in PMF patient serum and, in addition, CXCR1 and CXCR2 participate in megakaryocyte proliferation and megakaryocyte ploidy [51]. In this regard, it is known that PMF patients exhibit aberrant immature megakaryocyte clusters, releasing a plethora of proinflammatory cytokines, a key mechanism that induces secondary fibrosis [33]. Much evidence suggests that the enhancement of the role of the FL/Flt3 axis in PMF could be associated with dysmegakaryopoiesis, as shown by an increased percentage of circulating $\mathrm{CD} 34^{+} \mathrm{Fl} 3^{+}$cells expressing the $\mathrm{CD} 41$ megakaryocyte antigen [55]. Among the most important chemokines, CXCL4, also known as platelet factor-4 (PF4), was proposed to play a crucial role in PMF pathogenesis in 1984 [56]. However, the underlying mechanism of action of CXCL4, produced by the clonal pathological hematopoietic stem cell, has been recently elucidated [57]. In fact, CXCL4 is able to reprogram GLI1, upregulating matrisome genes, a prelude to fibrosis development. Furthermore, in MPN mouse models, CXCL4 knockdown prevents the upregulation of inflammatory pathways and TGF-beta, improving most of the main clinical signs observed in such a preclinical model such as anemia, thrombocytosis, splenomegaly and aberrant megakaryocytes in bone marrow. Finally, the upregulation of the JAK/STAT pathway induced by CXCL4 has been also reported, even though it seems this is not sufficient to develop fibrosis, whereas other mechanisms might coexist and cooperate.

\section{The Biochemical Network of Osteosclerosis in PMF}

Bone modifications are a pathognomonic hallmark of PMF since they represent one of the direct results of bone marrow disruption. Osteosclerosis remains the most common bone change, which represents a pathological event characterized by increased bone density and abnormal hardening [58-60], and its pathogenesis is still largely unknown. 
Osteosclerotic regions are produced by the irregular thickening of bone trabeculae, new bone shaping and consequent bone volume growth. In particular, increased bone marrow activity in some regions, such as the vertebral column, pelvis or proximal segments of long bones, remain the most affected by such alterations $[58,60]$. The physiological bone morphology and functionality are strictly dependent on the accurate setting of the marrow osteoblastic niche as well as the balance between mature bone tissue, endosteum and central bone marrow [61,62].

\subsection{Bone Marrow as Bone Remodeling "Workshop"}

Bone tissue homeostasis is controlled by the cooperation of both HSCs and MSCs, involved in the differentiation in osteoclasts (OCs) and osteoblasts (OBs), respectively. OBs share their mesenchymal biogenesis with chondrocytes, adipocytes and stromal cells [63-66]. As such, bone marrow hematopoiesis and bone turnover have a morphological and functional interconnection, and both these processes affect each other. The osteoblastic niche holds different cell lineages that support HSC multipotency and self-renewal through reciprocal interactions, including bone-matrix-forming OBs and bone-resorbing OCs [67]. The development of OCs from HSCs provides a first step of monocytes/macrophage differentiation as progenitor cells, followed by the subsequent formation of mononuclear OCs. Although these cells already show bone-resorbing activity, they subsequently fuse to produce multinuclear osteoclasts in order to perform their specific functions toward bone remodeling [68]. Conversely, OBs originate from mesenchymal-lineage MSCs and undergo two different processes: they become quiescent cells on the bone surface, known as the bone lining cell, or they differentiate into mature osteocytes $[69,70]$. Spindle-shaped N-cadherin-expressing osteoblasts (SNOs), a subset of osteoblastic lining cells in the trabecular bone area, prevent the differentiation process of HSCs, keeping them long-term quiescent. These resting cells coexist with the activated HSCs, which are recruited to differentiate from the vascular niche in response to microenvironmental changes [62]. In this regard, activated OBs regulate HSC quiescence through the secretion of angiopoietin-1 (Ang 1) and osteopontin (OPN) [71]; at the same time, OCs release calcium during bone resorption in order to contribute to enhancing HSC localization into bone marrow [72]. Similarly, CD146-positive OB progenitor subendothelial stromal cells are regarded as a critical component of the endosteal HSC niche and contribute to the organization and structure of sinusoidal walls, expressing HSC regulators such as Ang-1 or CXCL12 [73]. In fact, while staying over sinusoids, they contribute to hematopoietic regulation, acting either directly as adventitial reticular cells or indirectly through their OB progeny at the endosteal surface [74]. Notably, CD146 or melanoma cell adhesion molecule (MCAM) has been associated with the late stage of the disease. In particular, a remarkable increase in CD146 expression in patients during the advanced phase of PMF has been reported [75]. A recent study confirmed the importance of the endosteal niche in HSC maintenance, assuming an interesting model of mutual interaction between aberrant myeloid cells caused by myeloproliferative expansion, MSC stimulation and OB overproduction [76].

\subsection{The OB/OC Ratio}

It is well established that osteosclerotic evolution in PMF is mainly due to the failure of the bone formation and bone resorption balance, and OBs and OCs represent the main characters of osteosclerosis pathogenesis. On the one hand, OBs are strongly induced to proliferate and differentiate [77]; on the other hand, osteoclastogenesis seems to be deeply impaired as a result of microenvironmental alterations involving osteoprotegerin (OPG), RANKL and macrophage colony-stimulating factor (M-CSF) expressions. In particular, recent evidence suggests that in PMF patients, OCs are generated by neoplastic monocytes after a low number of fusion events, providing an abnormal morphology and impaired resorption capacity [78]. In this context, bone regeneration overcomes the bone resorption process, resulting in osteosclerotic deposition. OB enhancement certainly represents a 
distinctive feature of osteosclerotic development in PMF [76,79], and this evidence is followed by concurrent OC impairment, which further exacerbates the severe imbalance toward bone remodeling [78]. However, while several data support the idea of maintained OB-OC coupling, decreased bone resorption suggests that the individual activity of OCs, similar to that of OBs, could also be decreased. The decline in OC activity is recognized as a positive balance by remodeling bone units, which could possibly lead to the growth of bone mass in patients [80]. OBs, in turn, are stimulated by excessive bone morphogenetic proteins BMP-2, -4 and -6 , mainly released by abnormal megakaryocytes [81] and also by growth factors able to induce their proliferation and differentiation, such as insulinlike growth factor I (IGF-I) and fibroblast growth factor (FGF) [77]. BMPs belong to the TGF- $\beta$ superfamily, and their release is associated with increased gene expression of type I collagen, osterix (Osx), osteocalcin, osteopontin (OPN), VEGF and PDGF $\alpha$ during osteoblastic differentiation [82]. Their involvement in neoangiogenesis and osteosclerosis, upregulating $\mathrm{OB}$ proliferation and differentiation, has been hypothesized on the basis of experimental evidence showing that megakaryocytes of GATA-1-low mice contribute to osteosclerosis by stimulating bone formation via the increased release of BMPs [83]. Moreover, their pathogenetic function in PMF seems to be correlated with alterations in the NOG gene encoding for the antagonist protein to BMP2 and BMP4 (NOGGIN) [82,84].

\subsection{The Monocytic Line: Role of Osteal Macrophages (OsteoMacs)}

Osteosclerosis associated with MPNs is a pathological evolution, typical of the advanced stage of myelofibrosis, which is due to the gradual replacement of marrow by collagen and bone trabeculae accomplished by activated myofibroblasts ( $\alpha$ SMA1-positive stromal cells) [85]. These types of cells differentiate by particular progenitors such as GLI1-positive and Lepr-positive stromal cells under the driving activity of megakaryocytes [86-88]. Many studies have revealed the importance of the monocyte line [89-91], highlighting the role of IL-1 release as well as TGF $\beta$ overproduction. In particular, bone-resident macrophages (OsteoMacs) have recently gained relevance in PMF clinical contexts because of their involvement in the differentiation of mesenchymal lineages [92-94], especially in OB functionality, through TNF $\alpha$ or oncostatin M $[95,96]$. It is well known that OsteoMacs contribute to bone repair mechanisms; after a proinflammatory stimulus, they release IL1 and $\mathrm{TNF} \alpha$ [97] and also secrete proanabolic factors to support osteogenic differentiation and OB maturation in vitro [95,98-100], closely cooperating with MSCs and stromal cells to form a deep partnership with the neighboring populations. Starting with this evidence, some studies confirmed the implication of the bone-associated macrophage lineage in the myelofibrotic and osteosclerotic course through a complex release of growth factors such as TGF $\beta$, CXCL4 and PDGF, in collaboration with megakaryocytes, as mentioned above. In this backdrop, the mutual regulation between megakaryocytes and macrophages in MPN progression has been hypothesized, and vitamin D seems to play a pivotal role in their crosstalk [101].

\subsection{RANKL/OPG Axis and the Wnt/b-Catenin Pathway}

Much evidence has been reported to support the role of osteoprotegerin (OPG) as a substantial marker involved in PMF pathogenesis [102,103]. Plasma OPG levels have been found significantly increased in PMF patients compared to healthy controls. OPG, a member of the TNFr superfamily [104], constitutes a key biomolecule in the bone remodeling process, regulating the inhibition of OC differentiation. Its up- or downregulation is involved in different pathological conditions associated with osteosclerosis [105] or osteoporosis [106,107], respectively. OPG hyperexpression particularly seems to support a double function. On the one hand, it impairs OC production and its differentiation process [108]; on the other hand, it sustains endothelial proliferation as well as neoangiogenesis [109,110]. OPG expression in OBs is regulated by many different cytokines, as well as by the Wnt/ $\beta$ catenin pathway [111] and Jagged1/Notch1 signaling, which directly inhibits osteoclastogenesis and indirectly affects the OPG-receptor activator of the NF-kB 
ligand (RANKL) expression ratio in stromal cells [112]. The main signaling pathway in bone resorption is indeed RANKL mediated. It is mainly expressed by osteoblastic stromal cells that bind to its receptor RANK on monocytes, OCPs and mature OCs, producing osteoclastogenesis $[113,114]$. RANKL is a homotrimeric protein existing like membrane-bound OBs in a $\mathrm{T}$ cell form or secretory protein form [115,116]. Increased RANKL expression in stromal cells is usually associated with the stimulation of osteoclastogenesis and OC progenitor (OCP) release [117-119]. Furthermore, RANKL represents a functional link between bone remodeling and hematopoiesis since RANKL-induced osteoclastogenesis affects HSC mobilization as well as hematopoietic activity [117]. Experimental evidence highlights a role of TGF $\beta$ on osteosclerotic progression together with OPG upregulation [105], while the stimulatory effect of TGF $\beta$ on OPG secretion in primary OBs and stromal cell lines has been confirmed by many other studies $[120,121]$. The RANKL/OPG ratio is an essential factor of bone mass regulation and integrity. In particular, OPG represents an inhibitor of bone resorption and protects bone binding to RANKL, impeding interaction to its receptor RANK (Figure 2). The canonical WNT/ $\beta$-catenin signaling pathway plays an important role during skeleton development, besides being important for bone mass. WNT signaling also regulates MSC differentiation into OBs, controlling bone formation, increasing OB proliferation and inhibiting $\mathrm{OB}$ apoptosis. It is also able to negatively regulate adipocyte, chondrocyte and OC differentiation. The canonical WNT / $\beta$-catenin signaling is a key mediator of the stem cell signaling network, in which different cytokine-induced cascades act in a context-dependent manner [122]. A major protagonist of this network is Wnt, a factor of fibroblast growth (FGF), Notch, transforming growth factor $b$ /bone morphogenetic protein (TGF-b/BMP) and sonic hedgehog signaling (SHH) cascades $[123,124]$. All these pathways promote bone remodeling, inducing MSC differentiation into mature OBs. Several works have demonstrated that $\mathrm{WNT} / \beta$-catenin signaling is involved in microenvironmental transformation in PMF [125]. Moreover, the SHH pathway has been found to be upregulated in PMF, suggesting a potential interplay with $\mathrm{WNT} / \beta$-catenin in mediating osteosclerotic mechanisms [126]. Recently, Yachoui and collaborators highlighted the role of endothelin-1 (ET1), a potent vasoconstrictor, as a key mediator of osteoblastic bone metastases by stimulating OB proliferation and new bone formation. The anabolic action of ET1 occurs through the activation of the WNT signaling pathway, reducing the expression of both DKK1 and SOST (inhibitors of canonical WNT signaling) and inducing the formation of new bone. These authors also demonstrated that PMF patients showed increased ET1 signaling, suggesting that it could be responsible for the osteosclerosis that developed with advanced myelofibrosis [127].

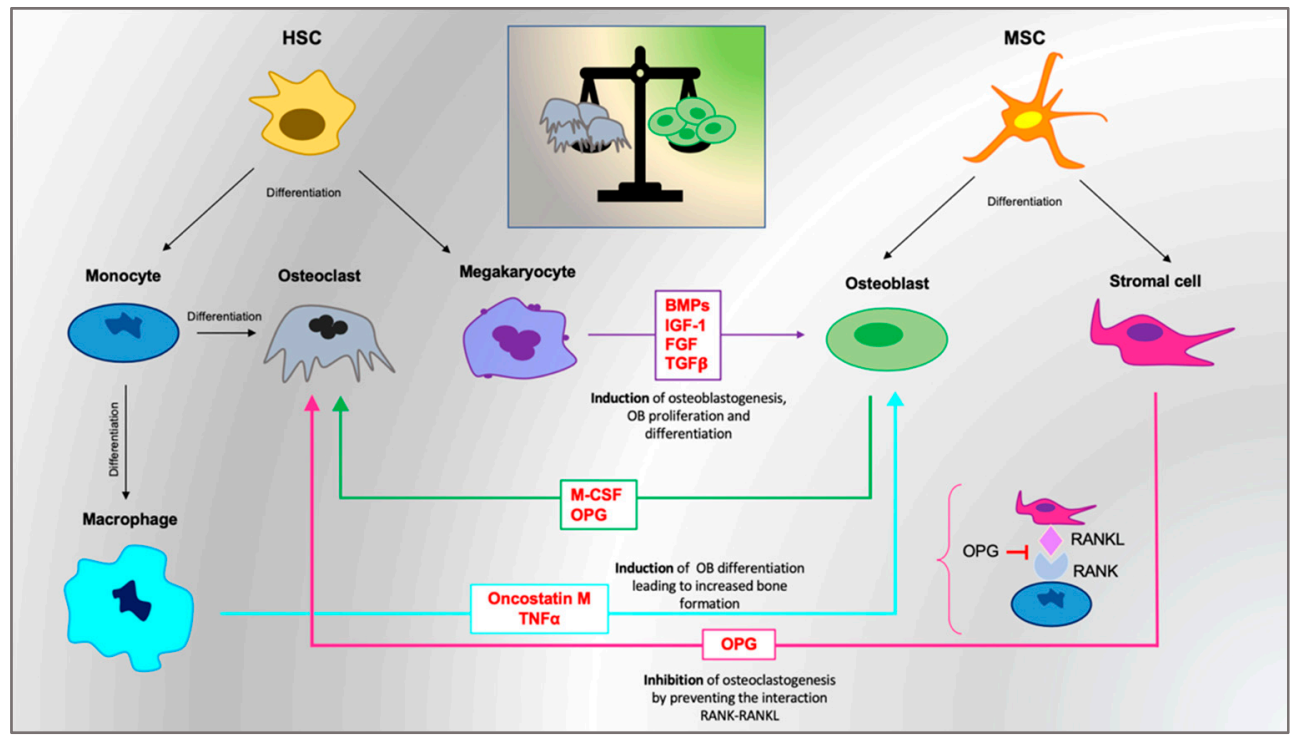

Figure 2. A schematic representation of osteosclerosis processes in primary myelofibrosis (PMF). 


\section{Conclusions}

PMF is a myeloproliferative syndrome with a very complex clinical background, characterized by general bone marrow failure with impaired hematopoiesis followed by extramedullary hematopoiesis, splenomegaly and progressive bone deposition replacing the fibrotic areas. Bone tissue deposition remains one of the mechanisms, together with fibrosis, associated with unavoidable progression. Although several mechanisms of PMF bone damage remain unknown, the involvement of many biomarkers and cell lineages constitutively present in the bone marrow microenvironment has been confirmed. Assuming that the physiological state of bone marrow is based on the continuous balance between the hematopoietic niche and bone remodeling, it is necessary to evaluate the most important factors involved in bone impairment and osteosclerosis. In particular, we summarized the central role of megakaryocytes and their alterations associated with the release of a plethora of cytokines and chemokines. Each of them represents a relevant factor, the activity of which seems to be absolutely interconnected with each bone marrow cell population, creating a network of impaired signaling that contributes to the overall imbalance of the bone marrow system. In this complex system, each cell line, associated with a specific panel of cytokines and signals, contributes to bone alterations and modifies the physiological functions, affecting the fine balance between OBs and OCs and, in turn, affecting bone formation and bone resorption homeostasis.

Author Contributions: Conceptualization, M.S., D.T., C.G., G.L.V., A.R. and G.A.P.; validation, A.R., M.D.R., M.S., G.A.P., D.T., L.L., N.V. and I.D.; writing-original draft preparation, M.S., D.T., C.G., G.A.P., G.S., G.L.V., L.L. and R.P.; supervision, D.T., G.A.P., V.B., N.V., R.A., R.P., E.L.S., G.S., R.A., I.D. and G.L.V. All authors have read and agreed to the published version of the manuscript.

Funding: This study was supported by Piano di Incentivi per la ricerca di Ateneo 2020/2022 Linea di intervento 2 (G.L.V.). C.G. was supported by the PON AIM R\&I 2014-2020-E68D19001340001. N.V. was supported by the PON AIM R\&I 2014-2020-E66C18001240007. This study was supported in part by A.I.L. (Associazione Italiana contro le Leucemie) sezione di Catania, FON.CA.NE.SA. (Fondazione Catanese per lo Studio delle Malattie Neoplastiche del Sangue).

Institutional Review Board Statement: Not applicable.

Informed Consent Statement: Not applicable.

Conflicts of Interest: The authors declare no conflict of interest.

\section{References}

1. Imai, M.; Araki, M.; Komatsu, N. Somatic mutations of calreticulin in myeloproliferative neoplasms. Int. J. Hematol. 2017, 105, 743-747. [CrossRef]

2. Di Rosa, M.; Giallongo, C.; Romano, A.; Tibullo, D.; Li Volti, G.; Musumeci, G.; Barbagallo, I.; Imbesi, R.; Castrogiovanni, P.; Palumbo, G.A. Immunoproteasome Genes Are Modulated in CD34 (+) JAK2 (V617F) Mutated Cells from Primary Myelofibrosis Patients. Int. J. Mol. Sci. 2020, 21, 2926. [CrossRef] [PubMed]

3. Longhitano, L.; Li Volti, G.; Giallongo, C.; Spampinato, M.; Barbagallo, I.; Di Rosa, M.; Romano, A.; Avola, R.; Tibullo, D.; Palumbo, G.A. The Role of Inflammation and Inflammasome in Myeloproliferative Disease. J. Clin. Med. 2020, 9, 2334. [CrossRef] [PubMed]

4. Palumbo, G.A.; Stella, S.; Pennisi, M.S.; Pirosa, C.; Fermo, E.; Fabris, S.; Cattaneo, D.; Iurlo, A. The Role of New Technologies in Myeloproliferative Neoplasms. Front. Oncol. 2019, 9, 321. [CrossRef] [PubMed]

5. Pikman, Y.; Lee, B.H.; Mercher, T.; McDowell, E.; Ebert, B.L.; Gozo, M.; Cuker, A.; Wernig, G.; Moore, S.; Galinsky, I.; et al. MPLW515L is a novel somatic activating mutation in myelofibrosis with myeloid metaplasia. PLoS Med. 2006, 3, e270. [CrossRef]

6. Vainchenker, W.; Kralovics, R. Genetic basis and molecular pathophysiology of classical myeloproliferative neoplasms. Blood 2017, 129, 667-679. [CrossRef]

7. Gangat, N.; Tefferi, A. Myelofibrosis biology and contemporary management. Br. J. Haematol. 2020, 191, 152-170. [CrossRef]

8. Wong, W.J.; Baltay, M.; Getz, A.; Fuhrman, K.; Aster, J.C.; Hasserjian, R.P.; Pozdnyakova, O. Gene expression profiling distinguishes prefibrotic from overtly fibrotic myeloproliferative neoplasms and identifies disease subsets with distinct inflammatory signatures. PLoS ONE 2019, 14, e0216810. [CrossRef]

9. Cokic, V.P.; Mitrovic-Ajtic, O.; Beleslin-Cokic, B.B.; Markovic, D.; Buac, M.; Diklic, M.; Kraguljac-Kurtovic, N.; Damjanovic, S.; Milenkovic, P.; Gotic, M.; et al. Proinflammatory Cytokine IL-6 and JAK-STAT Signaling Pathway in Myeloproliferative Neoplasms. Mediat. Inflamm. 2015, 2015, 453020. [CrossRef] 
10. Woods, B.; Chen, W.; Chiu, S.; Marinaccio, C.; Fu, C.; Gu, L.; Bulic, M.; Yang, Q.; Zouak, A.; Jia, S.; et al. Activation of JAK/STAT Signaling in Megakaryocytes Sustains Myeloproliferation In Vivo. Clin. Cancer Res. 2019, 25, 5901-5912. [CrossRef]

11. Kleppe, M.; Kwak, M.; Koppikar, P.; Riester, M.; Keller, M.; Bastian, L.; Hricik, T.; Bhagwat, N.; McKenney, A.S.; Papalexi, E.; et al. JAK-STAT pathway activation in malignant and nonmalignant cells contributes to MPN pathogenesis and therapeutic response. Cancer Discov. 2015, 5, 316-331. [CrossRef] [PubMed]

12. Khan, I.; Huang, Z.; Wen, Q.; Stankiewicz, M.J.; Gilles, L.; Goldenson, B.; Schultz, R.; Diebold, L.; Gurbuxani, S.; Finke, C.M.; et al. AKT is a therapeutic target in myeloproliferative neoplasms. Leukemia 2013, 27, 1882-1890. [CrossRef] [PubMed]

13. Fisher, D.A.C.; Malkova, O.; Engle, E.K.; Miner, C.A.; Fulbright, M.C.; Behbehani, G.K.; Collins, T.B.; Bandyopadhyay, S.; Zhou, A.; Nolan, G.P.; et al. Mass cytometry analysis reveals hyperactive NF Kappa B signaling in myelofibrosis and secondary acute myeloid leukemia. Leukemia 2017, 31, 1962-1974. [CrossRef] [PubMed]

14. Meier, B.; Burton, J.H. Myeloproliferative disorders. Emerg. Med. Clin. N. Am. 2014, 32, 597-612. [CrossRef]

15. Moulard, O.; Mehta, J.; Fryzek, J.; Olivares, R.; Iqbal, U.; Mesa, R.A. Epidemiology of myelofibrosis, essential thrombocythemia, and polycythemia vera in the European Union. Eur. J. Haematol. 2014, 92, 289-297. [CrossRef]

16. Harrison, C.N.; Schaap, N.; Mesa, R.A. Management of myelofibrosis after ruxolitinib failure. Ann. Hematol. 2020, 99, 1177-1191. [CrossRef]

17. Polverelli, N.; Palumbo, G.A.; Binotto, G.; Abruzzese, E.; Benevolo, G.; Bergamaschi, M.; Tieghi, A.; Bonifacio, M.; Breccia, M.; Catani, L.; et al. Epidemiology, outcome, and risk factors for infectious complications in myelofibrosis patients receiving ruxolitinib: A multicenter study on 446 patients. Hematol. Oncol. 2018, 36, 561-569. [CrossRef]

18. Tefferi, A.; Lasho, T.L.; Jimma, T.; Finke, C.M.; Gangat, N.; Vaidya, R.; Begna, K.H.; Al-Kali, A.; Ketterling, R.P.; Hanson, C.A.; et al. One thousand patients with primary myelofibrosis: The mayo clinic experience. Mayo Clin. Proc. 2012, 87, 25-33. [CrossRef]

19. Tefferi, A. Primary myelofibrosis: 2019 update on diagnosis, risk-stratification and management. Am. J. Hematol. 2018, 93, 1551-1560. [CrossRef]

20. Polverelli, N.; Elli, E.M.; Abruzzese, E.; Palumbo, G.A.; Benevolo, G.; Tiribelli, M.; Bonifacio, M.; Tieghi, A.; Caocci, G.; D'Adda, M.; et al. Second primary malignancy in myelofibrosis patients treated with ruxolitinib. Br. J. Haematol. 2020. [CrossRef]

21. Koschmieder, S.; Mughal, T.I.; Hasselbalch, H.C.; Barosi, G.; Valent, P.; Kiladjian, J.J.; Jeryczynski, G.; Gisslinger, H.; Jutzi, J.S.; Pahl, H.L.; et al. Myeloproliferative neoplasms and inflammation: Whether to target the malignant clone or the inflammatory process or both. Leukemia 2016, 30, 1018-1024. [CrossRef] [PubMed]

22. Elli, E.M.; Barate, C.; Mendicino, F.; Palandri, F.; Palumbo, G.A. Mechanisms Underlying the Anti-inflammatory and Immunosuppressive Activity of Ruxolitinib. Front. Oncol. 2019, 9, 1186. [CrossRef] [PubMed]

23. Song, M.K.; Park, B.B.; Uhm, J.E. Understanding Splenomegaly in Myelofibrosis: Association with Molecular Pathogenesis. Int. J. Mol. Sci. 2018, 19, 898. [CrossRef] [PubMed]

24. Tefferi, A. The forgotten myeloproliferative disorder: Myeloid metaplasia. Oncologist 2003, 8, 225-231. [CrossRef] [PubMed]

25. Cervantes, F. How I treat splenomegaly in myelofibrosis. Blood Cancer J. 2011, 1, e37. [CrossRef] [PubMed]

26. Palandri, F.; Palumbo, G.A.; Abruzzese, E.; Iurlo, A.; Polverelli, N.; Elli, E.; Bonifacio, M.; Bergamaschi, M.; Martino, B.; Tiribelli, M.; et al. Impact of 2016 WHO diagnosis of early and overt primary myelofibrosis on presentation and outcome of 232 patients treated with ruxolitinib. Hematol. Oncol. 2019, 37, 418-423. [CrossRef]

27. Palandri, F.; Palumbo, G.A.; Bonifacio, M.; Breccia, M.; Latagliata, R.; Martino, B.; Polverelli, N.; Abruzzese, E.; Tiribelli, M.; Nicolosi, M.; et al. Durability of spleen response affects the outcome of ruxolitinib-treated patients with myelofibrosis: Results from a multicentre study on 284 patients. Leuk. Res. 2018, 74, 86-88. [CrossRef]

28. Calvi, L.M.; Adams, G.B.; Weibrecht, K.W.; Weber, J.M.; Olson, D.P.; Knight, M.C.; Martin, R.P.; Schipani, E.; Divieti, P.; Bringhurst, F.R.; et al. Osteoblastic cells regulate the haematopoietic stem cell niche. Nature 2003, 425, 841-846. [CrossRef]

29. Hooper, A.T.; Butler, J.M.; Nolan, D.J.; Kranz, A.; Iida, K.; Kobayashi, M.; Kopp, H.G.; Shido, K.; Petit, I.; Yanger, K.; et al. Engraftment and reconstitution of hematopoiesis is dependent on VEGFR2-mediated regeneration of sinusoidal endothelial cells. Cell Stem Cell 2009, 4, 263-274. [CrossRef]

30. Yin, T.; Li, L. The stem cell niches in bone. J. Clin. Invest. 2006, 116, 1195-1201. [CrossRef]

31. O'Sullivan, J.M.; Harrison, C.N. Myelofibrosis: Clinicopathologic features, prognosis, and management. Clin. Adv. Hematol. Oncol. 2018, 16, 121-131. [PubMed]

32. Nazha, A.; Khoury, J.D.; Rampal, R.K.; Daver, N. Fibrogenesis in Primary Myelofibrosis: Diagnostic, Clinical, and Therapeutic Implications. Oncologist 2015, 20, 1154-1160. [CrossRef] [PubMed]

33. Ciurea, S.O.; Merchant, D.; Mahmud, N.; Ishii, T.; Zhao, Y.; Hu, W.; Bruno, E.; Barosi, G.; Xu, M.; Hoffman, R. Pivotal contributions of megakaryocytes to the biology of idiopathic myelofibrosis. Blood 2007, 110, 986-993. [CrossRef] [PubMed]

34. Wang, J.C.; Novetsky, A.; Chen, C.; Novetsky, A.D. Plasma matrix metalloproteinase and tissue inhibitor of metalloproteinase in patients with agnogenic myeloid metaplasia or idiopathic primary myelofibrosis. Br. J. Haematol. 2002, 119, 709-712. [CrossRef]

35. Vannucchi, A.M.; Bianchi, L.; Cellai, C.; Paoletti, F.; Rana, R.A.; Lorenzini, R.; Migliaccio, G.; Migliaccio, A.R. Development of myelofibrosis in mice genetically impaired for GATA-1 expression (GATA-1 (low) mice). Blood 2002, 100, 1123-1132. [CrossRef]

36. Abbonante, V.; Di Buduo, C.A.; Gruppi, C.; Malara, A.; Gianelli, U.; Celesti, G.; Anselmo, A.; Laghi, L.; Vercellino, M.; Visai, L.; et al. Thrombopoietin/TGF-beta1 Loop Regulates Megakaryocyte Extracellular Matrix Component Synthesis. Stem Cells 2016, 34, 1123-1133. [CrossRef] 
37. Jacobson, R.J.; Salo, A.; Fialkow, P.J. Agnogenic myeloid metaplasia: A clonal proliferation of hematopoietic stem cells with secondary myelofibrosis. Blood 1978, 51, 189-194. [CrossRef]

38. Reeder, T.L.; Bailey, R.J.; Dewald, G.W.; Tefferi, A. Both B and T lymphocytes may be clonally involved in myelofibrosis with myeloid metaplasia. Blood 2003, 101, 1981-1983. [CrossRef]

39. Reilly, J.T. Idiopathic myelofibrosis: Pathogenesis, natural history and management. Blood Rev. 1997, 11, 233-242. [CrossRef]

40. Dong, M.; Blobe, G.C. Role of transforming growth factor-beta in hematologic malignancies. Blood 2006, 107, 4589-4596. [CrossRef]

41. Martyre, M.C.; Romquin, N.; Le Bousse-Kerdiles, M.C.; Chevillard, S.; Benyahia, B.; Dupriez, B.; Demory, J.L.; Bauters, F. Transforming growth factor-beta and megakaryocytes in the pathogenesis of idiopathic myelofibrosis. Br. J. Haematol. 1994, 88, 9-16. [CrossRef] [PubMed]

42. Yanagida, M.; Ide, Y.; Imai, A.; Toriyama, M.; Aoki, T.; Harada, K.; Izumi, H.; Uzumaki, H.; Kusaka, M.; Tokiwa, T. The role of transforming growth factor-beta in PEG-rHuMGDF-induced reversible myelofibrosis in rats. Br. J. Haematol. 1997, 99, 739-745. [CrossRef] [PubMed]

43. Farmer, S.; Vestergaard, H.; Hansen, S.; Shanbhogue, V.V.; Stahlberg, C.I.; Hermann, A.P.; Frederiksen, H. Bone geometry, bone mineral density, and micro-architecture in patients with myelofibrosis: A cross-sectional study using DXA, HR-pQCT, and bone turnover markers. Int J. Hematol. 2015, 102, 67-75. [CrossRef] [PubMed]

44. Wagner-Ballon, O.; Chagraoui, H.; Prina, E.; Tulliez, M.; Milon, G.; Raslova, H.; Villeval, J.L.; Vainchenker, W.; Giraudier, S. Monocyte/macrophage dysfunctions do not impair the promotion of myelofibrosis by high levels of thrombopoietin. J. Immunol. 2006, 176, 6425-6433. [CrossRef] [PubMed]

45. Hasselbalch, H.C. Chronic inflammation as a promotor of mutagenesis in essential thrombocythemia, polycythemia vera and myelofibrosis. A human inflammation model for cancer development? Leuk. Res. 2013, 37, 214-220. [CrossRef]

46. Desterke, C.; Martinaud, C.; Ruzehaji, N.; Le Bousse-Kerdiles, M.C. Inflammation as a Keystone of Bone Marrow Stroma Alterations in Primary Myelofibrosis. Mediat. Inflamm. 2015, 2015, 415024. [CrossRef] [PubMed]

47. Leiva, O.; Ng, S.K.; Chitalia, S.; Balduini, A.; Matsuura, S.; Ravid, K. The role of the extracellular matrix in primary myelofibrosis. Blood Cancer J. 2017, 7, e525. [CrossRef]

48. Orkin, S.H.; Shivdasani, R.A.; Fujiwara, Y.; McDevitt, M.A. Transcription factor GATA-1 in megakaryocyte development. Stem Cells 1998, 16 (Suppl. 2), 79-83. [CrossRef]

49. Villeval, J.L.; Cohen-Solal, K.; Tulliez, M.; Giraudier, S.; Guichard, J.; Burstein, S.A.; Cramer, E.M.; Vainchenker, W.; Wendling, F. High thrombopoietin production by hematopoietic cells induces a fatal myeloproliferative syndrome in mice. Blood 1997, 90, 4369-4383. [CrossRef]

50. Tefferi, A.; Lavu, S.; Mudireddy, M.; Lasho, T.L.; Finke, C.M.; Gangat, N.; Pardanani, A.; Hanson, C.A.; Mannarelli, C.; Guglielmelli, P.; et al. JAK2 exon 12 mutated polycythemia vera: Mayo-Careggi MPN Alliance study of 33 consecutive cases and comparison with JAK2V617F mutated disease. Am. J. Hematol. 2018, 93, E93-E96. [CrossRef]

51. Emadi, S.; Clay, D.; Desterke, C.; Guerton, B.; Maquarre, E.; Charpentier, A.; Jasmin, C.; Le Bousse-Kerdiles, M.C.; French INSERM Research Network on MMM. IL-8 and its CXCR1 and CXCR2 receptors participate in the control of megakaryocytic proliferation, differentiation, and ploidy in myeloid metaplasia with myelofibrosis. Blood 2005, 105, 464-473. [CrossRef] [PubMed]

52. Matsushima, K.; Oppenheim, J.J. Interleukin 8 and MCAF: Novel inflammatory cytokines inducible by IL 1 and TNF. Cytokine 1989, 1, 2-13. [CrossRef]

53. Hashimoto, S.; Yoda, M.; Yamada, M.; Yanai, N.; Kawashima, T.; Motoyoshi, K. Macrophage colony-stimulating factor induces interleukin-8 production in human monocytes. Exp. Hematol. 1996, 24, 123-128. [PubMed]

54. Takeuchi, K.; Higuchi, T.; Yamashita, T.; Koike, K. Chemokine production by human megakaryocytes derived from CD34-positive cord blood cells. Cytokine 1999, 11, 424-434. [CrossRef]

55. Cuadrado, A.; Nebreda, A.R. Mechanisms and functions of p38 MAPK signalling. Biochem. J. 2010, 429, 403-417. [CrossRef]

56. Burstein, S.A.; Malpass, T.W.; Yee, E.; Kadin, M.; Brigden, M.; Adamson, J.W.; Harker, L.A. Platelet factor-4 excretion in myeloproliferative disease: Implications for the aetiology of myelofibrosis. Br. J. Haematol. 1984, 57, 383-392. [CrossRef]

57. Gleitz, H.F.E.; Dugourd, A.J.F.; Leimkuhler, N.B.; Snoeren, I.A.M.; Fuchs, S.N.R.; Menzel, S.; Ziegler, S.; Kroger, N.; Triviai, I.; Busche, G.; et al. Increased CXCL4 expression in hematopoietic cells links inflammation and progression of bone marrow fibrosis in MPN. Blood 2020, 136, 2051-2064. [CrossRef]

58. Bucelli, C.; Cattaneo, D.; Valli, V.B.; Levati, G.V.; Lonati, S.; Gianelli, U.; Iurlo, A. Osteolytic Lesions in Primary Myelofibrosis and Effect of Ruxolitinib Therapy: Report of a Case and Literature Review. Chemotherapy 2018, 63, 340-344. [CrossRef]

59. Roberts, B.E.; Woods, C.G.; Miles, D.W.; Paterson, C.R. Bone changes in polycythaemia vera and myelosclerosis. J. Clin. Pathol. 1969, 22, 696-700. [CrossRef]

60. Merry, G.M.; Aronowitz, P.B. Myelofibrosis with massive hepatosplenomegaly and osteolytic bone lesions. J. Hosp. Med. 2010, 5, E27-E28. [CrossRef]

61. Levesque, J.P.; Helwani, F.M.; Winkler, I.G. The endosteal 'osteoblastic' niche and its role in hematopoietic stem cell homing and mobilization. Leukemia 2010, 24, 1979-1992. [CrossRef] [PubMed]

62. Del Fattore, A.; Capannolo, M.; Rucci, N. Bone and bone marrow: The same organ. Arch. Biochem. Biophys. 2010, 503, 28-34. [CrossRef] [PubMed]

63. Pittenger, M.F.; Mackay, A.M.; Beck, S.C.; Jaiswal, R.K.; Douglas, R.; Mosca, J.D.; Moorman, M.A.; Simonetti, D.W.; Craig, S.; Marshak, D.R. Multilineage potential of adult human mesenchymal stem cells. Science 1999, 284, 143-147. [CrossRef] [PubMed] 
64. Calabrese, G.; Giuffrida, R.; Forte, S.; Salvatorelli, L.; Fabbi, C.; Figallo, E.; Gulisano, M.; Parenti, R.; Magro, G.; Colarossi, C.; et al. Bone augmentation after ectopic implantation of a cell-free collagen-hydroxyapatite scaffold in the mouse. Sci. Rep. 2016, 6, 36399. [CrossRef] [PubMed]

65. Calabrese, G.; Forte, S.; Gulino, R.; Cefali, F.; Figallo, E.; Salvatorelli, L.; Maniscalchi, E.T.; Angelico, G.; Parenti, R.; Gulisano, M.; et al. Combination of Collagen-Based Scaffold and Bioactive Factors Induces Adipose-Derived Mesenchymal Stem Cells Chondrogenic Differentiation In Vitro. Front. Physiol. 2017, 8, 50. [CrossRef]

66. Lo Furno, D.; Mannino, G.; Cardile, V.; Parenti, R.; Giuffrida, R. Potential Therapeutic Applications of Adipose-Derived Mesenchymal Stem Cells. Stem Cells Dev. 2016, 25, 1615-1628. [CrossRef]

67. Morrison, S.J.; Scadden, D.T. The bone marrow niche for haematopoietic stem cells. Nature 2014, 505, 327-334. [CrossRef]

68. Miyamoto, T.; Suda, T. Differentiation and function of osteoclasts. Keio J. Med. 2003, 52, 1-7. [CrossRef]

69. Lee, W.C.; Guntur, A.R.; Long, F.; Rosen, C.J. Energy Metabolism of the Osteoblast: Implications for Osteoporosis. Endocr. Rev. 2017, 38, 255-266. [CrossRef]

70. Dallas, S.L.; Prideaux, M.; Bonewald, L.F. The osteocyte: An endocrine cell ... and more. Endocr. Rev. 2013, 34, 658-690. [CrossRef]

71. Boulais, P.E.; Frenette, P.S. Making sense of hematopoietic stem cell niches. Blood 2015, 125, 2621-2629. [CrossRef] [PubMed]

72. Adams, G.B.; Chabner, K.T.; Alley, I.R.; Olson, D.P.; Szczepiorkowski, Z.M.; Poznansky, M.C.; Kos, C.H.; Pollak, M.R.; Brown, E.M.; Scadden, D.T. Stem cell engraftment at the endosteal niche is specified by the calcium-sensing receptor. Nature 2006, 439, 599-603. [CrossRef] [PubMed]

73. Kiel, M.J.; Yilmaz, O.H.; Iwashita, T.; Yilmaz, O.H.; Terhorst, C.; Morrison, S.J. SLAM family receptors distinguish hematopoietic stem and progenitor cells and reveal endothelial niches for stem cells. Cell 2005, 121, 1109-1121. [CrossRef] [PubMed]

74. Sacchetti, B.; Funari, A.; Michienzi, S.; Di Cesare, S.; Piersanti, S.; Saggio, I.; Tagliafico, E.; Ferrari, S.; Robey, P.G.; Riminucci, M.; et al. Self-renewing osteoprogenitors in bone marrow sinusoids can organize a hematopoietic microenvironment. Cell 2007, 131, 324-336. [CrossRef] [PubMed]

75. Tripodo, C.; Di Bernardo, A.; Ternullo, M.P.; Guarnotta, C.; Porcasi, R.; Ingrao, S.; Gianelli, U.; Boveri, E.; Iannitto, E.; Franco, G.; et al. CD146 (+) bone marrow osteoprogenitors increase in the advanced stages of primary myelofibrosis. Haematologica 2009, 94, 127-130. [CrossRef]

76. Schepers, K.; Pietras, E.M.; Reynaud, D.; Flach, J.; Binnewies, M.; Garg, T.; Wagers, A.J.; Hsiao, E.C.; Passegue, E. Myeloproliferative neoplasia remodels the endosteal bone marrow niche into a self-reinforcing leukemic niche. Cell Stem Cell 2013, 13, 285-299. [CrossRef]

77. Centrella, M.; Horowitz, M.C.; Wozney, J.M.; McCarthy, T.L. Transforming growth factor-beta gene family members and bone. Endocr. Rev. 1994, 15, 27-39. [CrossRef]

78. Veletic, I.; Manshouri, T.; Multani, A.S.; Yin, C.C.; Chen, L.; Verstovsek, S.; Estrov, Z. Myelofibrosis osteoclasts are clonal and functionally impaired. Blood 2019, 133, 2320-2324. [CrossRef]

79. Thiele, J.; Kvasnicka, H.M. Myelofibrosis in chronic myeloproliferative disorders-dynamics and clinical impact. Histol. Histopathol. 2006, 21, 1367-1378. [CrossRef]

80. Coindre, J.M.; Reiffers, J.; Goussot, J.F.; De Mascarel, A.; Broustet, A. Histomorphometric analysis of sclerotic bone from idiopathic myeloid metaplasia (nine cases). J. Pathol. 1984, 144, 163-169. [CrossRef]

81. Krause, D.S.; Scadden, D.T.; Preffer, F.I. The hematopoietic stem cell niche-Home for friend and foe? Cytom. B Clin. Cytom. 2013, 84, 7-20. [CrossRef] [PubMed]

82. Andrieux, J.; Roche-Lestienne, C.; Geffroy, S.; Desterke, C.; Grardel, N.; Plantier, I.; Selleslag, D.; Demory, J.L.; Lai, J.L.; Leleu, X.; et al. Bone morphogenetic protein antagonist gene NOG is involved in myeloproliferative disease associated with myelofibrosis. Cancer Genet. Cytogenet. 2007, 178, 11-16. [CrossRef]

83. Garimella, R.; Kacena, M.A.; Tague, S.E.; Wang, J.; Horowitz, M.C.; Anderson, H.C. Expression of bone morphogenetic proteins and their receptors in the bone marrow megakaryocytes of GATA-1 (low) mice: A possible role in osteosclerosis. J. Histochem. Cytochem. 2007, 55, 745-752. [CrossRef] [PubMed]

84. Pera, M.F.; Andrade, J.; Houssami, S.; Reubinoff, B.; Trounson, A.; Stanley, E.G.; Ward-van Oostwaard, D.; Mummery, C. Regulation of human embryonic stem cell differentiation by BMP-2 and its antagonist noggin. J. Cell Sci. 2004, 117, 1269-1280. [CrossRef] [PubMed]

85. Tefferi, A. Myelofibrosis with myeloid metaplasia. N. Engl. J. Med. 2000, 342, 1255-1265. [CrossRef] [PubMed]

86. Kramann, R.; Schneider, R.K. The identification of fibrosis-driving myofibroblast precursors reveals new therapeutic avenues in myelofibrosis. Blood 2018, 131, 2111-2119. [CrossRef]

87. Schneider, R.K.; Mullally, A.; Dugourd, A.; Peisker, F.; Hoogenboezem, R.; Van Strien, P.M.H.; Bindels, E.M.; Heckl, D.; Busche, G.; Fleck, D.; et al. Gli1 (+) Mesenchymal Stromal Cells Are a Key Driver of Bone Marrow Fibrosis and an Important Cellular Therapeutic Target. Cell Stem Cell 2017, 20, 785-800.e788. [CrossRef]

88. Decker, M.; Martinez-Morentin, L.; Wang, G.; Lee, Y.; Liu, Q.; Leslie, J.; Ding, L. Leptin-receptor-expressing bone marrow stromal cells are myofibroblasts in primary myelofibrosis. Nat. Cell Biol. 2017, 19, 677-688. [CrossRef]

89. Rameshwar, P.; Denny, T.N.; Stein, D.; Gascon, P. Monocyte adhesion in patients with bone marrow fibrosis is required for the production of fibrogenic cytokines. Potential role for interleukin-1 and TGF-beta. J. Immunol. 1994, 153, 2819-2830. 
90. Rameshwar, P.; Narayanan, R.; Qian, J.; Denny, T.N.; Colon, C.; Gascon, P. NF-kappa B as a central mediator in the induction of TGF-beta in monocytes from patients with idiopathic myelofibrosis: An inflammatory response beyond the realm of homeostasis. J. Immunol. 2000, 165, 2271-2277. [CrossRef]

91. Chang, V.T.; Yook, C.; Rameshwar, P. Synergism between fibronectin and transforming growth factor-beta1 in the production of substance $\mathrm{P}$ in monocytes of patients with myelofibrosis. Leuk. Lymphoma 2013, 54, 631-638. [CrossRef] [PubMed]

92. Chow, A.; Lucas, D.; Hidalgo, A.; Mendez-Ferrer, S.; Hashimoto, D.; Scheiermann, C.; Battista, M.; Leboeuf, M.; Prophete, C.; van Rooijen, N.; et al. Bone marrow CD169+ macrophages promote the retention of hematopoietic stem and progenitor cells in the mesenchymal stem cell niche. J. Exp. Med. 2011, 208, 261-271. [CrossRef]

93. Winkler, I.G.; Sims, N.A.; Pettit, A.R.; Barbier, V.; Nowlan, B.; Helwani, F.; Poulton, I.J.; van Rooijen, N.; Alexander, K.A.; Raggatt, L.J.; et al. Bone marrow macrophages maintain hematopoietic stem cell (HSC) niches and their depletion mobilizes HSCs. Blood 2010, 116, 4815-4828. [CrossRef]

94. Christopher, M.J.; Rao, M.; Liu, F.; Woloszynek, J.R.; Link, D.C. Expression of the G-CSF receptor in monocytic cells is sufficient to mediate hematopoietic progenitor mobilization by G-CSF in mice. J. Exp. Med. 2011, 208, 251-260. [CrossRef]

95. Guihard, P.; Danger, Y.; Brounais, B.; David, E.; Brion, R.; Delecrin, J.; Richards, C.D.; Chevalier, S.; Redini, F.; Heymann, D.; et al. Induction of osteogenesis in mesenchymal stem cells by activated monocytes/macrophages depends on oncostatin $\mathrm{M}$ signaling. Stem Cells 2012, 30, 762-772. [CrossRef]

96. Sinder, B.P.; Pettit, A.R.; McCauley, L.K. Macrophages: Their Emerging Roles in Bone. J. Bone Miner. Res. 2015, 30, $2140-2149$. [CrossRef]

97. Kon, T.; Cho, T.J.; Aizawa, T.; Yamazaki, M.; Nooh, N.; Graves, D.; Gerstenfeld, L.C.; Einhorn, T.A. Expression of osteoprotegerin, receptor activator of NF-kappaB ligand (osteoprotegerin ligand) and related proinflammatory cytokines during fracture healing. J. Bone Miner. Res. 2001, 16, 1004-1014. [CrossRef] [PubMed]

98. Chang, M.K.; Raggatt, L.J.; Alexander, K.A.; Kuliwaba, J.S.; Fazzalari, N.L.; Schroder, K.; Maylin, E.R.; Ripoll, V.M.; Hume, D.A.; Pettit, A.R. Osteal tissue macrophages are intercalated throughout human and mouse bone lining tissues and regulate osteoblast function In Vitro and In Vivo. J. Immunol. 2008, 181, 1232-1244. [CrossRef]

99. Nicolaidou, V.; Wong, M.M.; Redpath, A.N.; Ersek, A.; Baban, D.F.; Williams, L.M.; Cope, A.P.; Horwood, N.J. Monocytes induce STAT3 activation in human mesenchymal stem cells to promote osteoblast formation. PLoS ONE 2012, 7, e39871. [CrossRef] [PubMed]

100. Alexander, K.A.; Chang, M.K.; Maylin, E.R.; Kohler, T.; Muller, R.; Wu, A.C.; Van Rooijen, N.; Sweet, M.J.; Hume, D.A.; Raggatt, L.J.; et al. Osteal macrophages promote in vivo intramembranous bone healing in a mouse tibial injury model. J. Bone Miner. Res. 2011, 26, 1517-1532. [CrossRef]

101. Wakahashi, K.; Minagawa, K.; Kawano, Y.; Kawano, H.; Suzuki, T.; Ishii, S.; Sada, A.; Asada, N.; Sato, M.; Kato, S.; et al. Vitamin D receptor-mediated skewed differentiation of macrophages initiates myelofibrosis and subsequent osteosclerosis. Blood 2019, 133, 1619-1629. [CrossRef]

102. Bock, O.; Loch, G.; Schade, U.; Busche, G.; Wasielewski, R.; Wiese, B.; Kreipe, H. Osteosclerosis in advanced chronic idiopathic myelofibrosis is associated with endothelial overexpression of osteoprotegerin. Br. J. Haematol. 2005, 130, 76-82. [CrossRef]

103. Wang, J.C.; Hemavathy, K.; Charles, W.; Zhang, H.; Dua, P.K.; Novetsky, A.D.; Chang, T.; Wong, C.; Jabara, M. Osteosclerosis in idiopathic myelofibrosis is related to the overproduction of osteoprotegerin (OPG). Exp. Hematol. 2004, 32, 905-910. [CrossRef]

104. Simonet, W.S.; Lacey, D.L.; Dunstan, C.R.; Kelley, M.; Chang, M.S.; Luthy, R.; Nguyen, H.Q.; Wooden, S.; Bennett, L.; Boone, T.; et al. Osteoprotegerin: A novel secreted protein involved in the regulation of bone density. Cell 1997, 89, 309-319. [CrossRef]

105. Chagraoui, H.; Tulliez, M.; Smayra, T.; Komura, E.; Giraudier, S.; Yun, T.; Lassau, N.; Vainchenker, W.; Wendling, F. Stimulation of osteoprotegerin production is responsible for osteosclerosis in mice overexpressing TPO. Blood 2003, 101, 2983-2989. [CrossRef]

106. Peng, Y.; Sheng, X.; Xue, F.; Qian, Y. The genetic association between osteoprotegerin (OPG) gene polymorphisms and bone mineral density (BMD) in postmenopausal women: A meta-analysis. Medicine 2018, 97, e13507. [CrossRef]

107. De Martinis, M.; Sirufo, M.M.; Suppa, M.; Ginaldi, L. IL-33/IL-31 Axis in Osteoporosis. Int. J. Mol. Sci. 2020, 21, 1239. [CrossRef]

108. Lacey, D.L.; Timms, E.; Tan, H.L.; Kelley, M.J.; Dunstan, C.R.; Burgess, T.; Elliott, R.; Colombero, A.; Elliott, G.; Scully, S.; et al. Osteoprotegerin ligand is a cytokine that regulates osteoclast differentiation and activation. Cell 1998, 93, 165-176. [CrossRef]

109. Malyankar, U.M.; Scatena, M.; Suchland, K.L.; Yun, T.J.; Clark, E.A.; Giachelli, C.M. Osteoprotegerin is an alpha vbeta 3-induced, NF-kappa B-dependent survival factor for endothelial cells. J. Biol. Chem. 2000, 275, 20959-20962. [CrossRef]

110. Mesa, R.A.; Steensma, D.P.; Pardanani, A.; Li, C.Y.; Elliott, M.; Kaufmann, S.H.; Wiseman, G.; Gray, L.A.; Schroeder, G.; Reeder, T.; et al. A phase 2 trial of combination low-dose thalidomide and prednisone for the treatment of myelofibrosis with myeloid metaplasia. Blood 2003, 101, 2534-2541. [CrossRef]

111. Glass, D.A., 2nd; Bialek, P.; Ahn, J.D.; Starbuck, M.; Patel, M.S.; Clevers, H.; Taketo, M.M.; Long, F.; McMahon, A.P.; Lang, R.A.; et al. Canonical Wnt signaling in differentiated osteoblasts controls osteoclast differentiation. Dev. Cell 2005, 8 , 751-764. [CrossRef] [PubMed]

112. Bai, S.; Kopan, R.; Zou, W.; Hilton, M.J.; Ong, C.T.; Long, F.; Ross, F.P.; Teitelbaum, S.L. NOTCH1 regulates osteoclastogenesis directly in osteoclast precursors and indirectly via osteoblast lineage cells. J. Biol. Chem. 2008, 283, 6509-6518. [CrossRef] [PubMed] 
113. Giovos, G.; Yavropoulou, M.P.; Yovos, J.G. The role of cellular senescence in diabetes mellitus and osteoporosis: Molecular pathways and potential interventions. Hormones 2019, 18, 339-351. [CrossRef] [PubMed]

114. Irelli, A.; Sirufo, M.M.; Scipioni, T.; De Pietro, F.; Pancotti, A.; Ginaldi, L.; De Martinis, M. mTOR Links Tumor Immunity and Bone Metabolism: What are the Clinical Implications? Int. J. Mol. Sci. 2019, 20, 5841. [CrossRef] [PubMed]

115. Kearns, A.E.; Khosla, S.; Kostenuik, P.J. Receptor activator of nuclear factor kappaB ligand and osteoprotegerin regulation of bone remodeling in health and disease. Endocr. Rev. 2008, 29, 155-192. [CrossRef]

116. Takayanagi, H. Osteoimmunology: Shared mechanisms and crosstalk between the immune and bone systems. Nat. Rev. Immunol. 2007, 7, 292-304. [CrossRef]

117. Kollet, O.; Dar, A.; Shivtiel, S.; Kalinkovich, A.; Lapid, K.; Sztainberg, Y.; Tesio, M.; Samstein, R.M.; Goichberg, P.; Spiegel, A.; et al. Osteoclasts degrade endosteal components and promote mobilization of hematopoietic progenitor cells. Nat. Med. 2006, 12, 657-664. [CrossRef]

118. Boyce, B.F.; Xing, L. Functions of RANKL/RANK/OPG in bone modeling and remodeling. Arch. Biochem. Biophys. 2008, 473, 139-146. [CrossRef]

119. Wada, T.; Nakashima, T.; Hiroshi, N.; Penninger, J.M. RANKL-RANK signaling in osteoclastogenesis and bone disease. Trends Mol. Med. 2006, 12, 17-25. [CrossRef]

120. Murakami, T.; Yamamoto, M.; Ono, K.; Nishikawa, M.; Nagata, N.; Motoyoshi, K.; Akatsu, T. Transforming growth factor-beta1 increases mRNA levels of osteoclastogenesis inhibitory factor in osteoblastic/stromal cells and inhibits the survival of murine osteoclast-like cells. Biochem. Biophys. Res. Commun. 1998, 252, 747-752. [CrossRef]

121. Thirunavukkarasu, K.; Miles, R.R.; Halladay, D.L.; Yang, X.; Galvin, R.J.; Chandrasekhar, S.; Martin, T.J.; Onyia, J.E. Stimulation of osteoprotegerin (OPG) gene expression by transforming growth factor-beta (TGF-beta). Mapping of the OPG promoter region that mediates TGF-beta effects. J. Biol. Chem. 2001, 276, 36241-36250. [CrossRef]

122. Grigorie, D.; Lerner, U.H. The Crucial Role of the Wnt System in Bone Remodelling. Acta Endocrinol. 2018, 14, 90-101. [CrossRef]

123. Tibullo, D.; Longo, A.; Vicario, N.; Romano, A.; Barbato, A.; Di Rosa, M.; Barbagallo, I.; Anfuso, C.D.; Lupo, G.; Gulino, R.; et al. Ixazomib Improves Bone Remodeling and Counteracts sonic Hedgehog signaling Inhibition Mediated by Myeloma Cells. Cancers 2020, 12, 323. [CrossRef]

124. Lucijanic, M.; Livun, A.; Tomasovic-Loncaric, C.; Stoos-Veic, T.; Pejsa, V.; Jaksic, O.; Prka, Z.; Kusec, R. Canonical Wnt/betaCatenin Signaling Pathway Is Dysregulated in Patients with Primary and Secondary Myelofibrosis. Clin. Lymphoma Myeloma Leuk. 2016, 16, 523-526. [CrossRef]

125. Vicario, N.; Bernstock, J.D.; Spitale, F.M.; Giallongo, C.; Giunta, M.A.S.; Li Volti, G.; Gulisano, M.; Leanza, G.; Tibullo, D.; Parenti, R.; et al. Clobetasol Modulates Adult Neural Stem Cell Growth via Canonical Hedgehog Pathway Activation. Int. J. Mol. Sci. 2019, 20, 1991. [CrossRef]

126. Gerds, A.T.; Tauchi, T.; Ritchie, E.; Deininger, M.; Jamieson, C.; Mesa, R.; Heaney, M.; Komatsu, N.; Minami, H.; Su, Y.; et al. Phase $1 / 2$ trial of glasdegib in patients with primary or secondary myelofibrosis previously treated with ruxolitinib. Leuk. Res. 2019, 79, 38-44. [CrossRef]

127. Yachoui, R.; Kristianto, J.; Sitwala, K.; Blank, R.D. Role of Endothelin-1 in a Syndrome of Myelofibrosis and Osteosclerosis. J. Clin. Endocrinol. Metab. 2015, 100, 3971-3974. [CrossRef] 